BNL-107630-2015-JA

Submitted to: Topics in Catalysis

\title{
Replacing Precious Metals with Carbide Catalysts for Hydrogenation Reactions
}

Ruijun $\mathrm{Hou}^{a, b}$, Kuan Chang ${ }^{a}$, Jingguang G. Chen ${ }^{b, c *}$, Tiefeng Wang ${ }^{a *}$

${ }^{a}$ Beijing Key Laboratory of Green Reaction Engineering and Technology

Department of Chemical Engineering, Tsinghua University, Beijing 100084, China

${ }^{b}$ Department of Chemical Engineering, Columbia University, New York, NY 10027, United States

${ }^{\mathrm{c} C h e m i s t r y ~ D e p a r t m e n t, ~ B r o o k h a v e n ~ N a t i o n a l ~ L a b o r a t o r y, ~ U p t o n, ~ N Y ~ 11973, ~ U n i t e d ~}$ States

* Corresponding Authors:

wangtf@tsinghua.edu.cn (T. F. Wang); Tel: 86-10-6279-4132

jgchen@columbia.edu (J.G. Chen); Tel: 1-212-854-6166 
Abstract: Molybdenum carbide $\left(\mathrm{Mo}_{2} \mathrm{C}\right.$ and $\left.\mathrm{Ni} / \mathrm{Mo}_{2} \mathrm{C}\right)$ catalysts were compared with $\mathrm{Pd} / \mathrm{SiO}_{2}$ for the hydrogenation of several diene molecules, 1,3- butadiene, 1,3and 1,4-cyclohexadiene (CHD). Compared to $\mathrm{Pd} / \mathrm{SiO}_{2}, \mathrm{Mo}_{2} \mathrm{C}$ showed similar hydrogenation rate for 1,3-butadiene and 1,3-CHD and even higher rate for 1,4-CHD, but with significant deactivation rate for 1,3-CHD hydrogenation. However, the hydrogenation activity of $\mathrm{Mo}_{2} \mathrm{C}$ could be completely regenerated by $\mathrm{H}_{2}$ treatment at $723 \mathrm{~K}$ for the three molecules. The $\mathrm{Ni}$ modified $\mathrm{Mo}_{2} \mathrm{C}$ catalysts retained similar activity for 1,3-butadiene hydrogenation with significantly enhanced selectivity for 1-butene production. The 1-butene selectivity increased with increasing Ni loading below $15 \%$. Among the $\mathrm{Ni}$ modified $\mathrm{Mo}_{2} \mathrm{C}$ catalysts, $8.6 \% \mathrm{Ni} / \mathrm{Mo}_{2} \mathrm{C}$ showed the highest selectivity to 1-butene, which was even higher selectivity than that over $\mathrm{Pd} / \mathrm{SiO}_{2}$. Compared to $\mathrm{Pd} / \mathrm{SiO}_{2}$, both $\mathrm{Mo}_{2} \mathrm{C}$ and $\mathrm{Ni} / \mathrm{Mo}_{2} \mathrm{C}$ showed combined advantages in hydrogenation activity and catalyst cost reduction, demonstrating the potential to use less expensive carbide catalysts to replace precious metals for hydrogenation reactions.

Keywords: Selective hydrogenation; 1,3-Buatdiene; Cyclohexadiene; Carbides 


\section{Introduction}

In manufacturing polymers, the catalytic hydrogenation of dienes is widely used for the purification of olefin stream. The hydrogenation catalysts commonly utilize supported precious metals, such as Pd-[1-3], Pt-[4-6], Rh-[7] or Au-[8, 9] based catalysts. The precious metal catalysts have shown high activity; however, their high cost and limited abundance are potential concerns for industrial applications. By forming bimetallic structures with a non-precious metal, the precious metal based catalysts could be enhanced in activity, thus lowering the catalyst cost. For example, by alloying Ni with $\mathrm{Pd}[10]$ or $\mathrm{Pt}[11,12]$, the activity in 1,3-butadiene hydrogenation could be increased. Recently, the $\mathrm{Al}_{13} \mathrm{Fe}_{4}$ surface[13] was found to be active in 1,3-butadiene hydrogenation under ultra-high vacuum environment, demonstrating the feasibility of using non-precious metal catalysts for diene hydrogenation.

Another class of non-precious metal hydrogenation catalysts are carbides of early transition metals, which often show catalytic properties similar to those of precious metals $[14,15]$. For example, molybdenum carbide $\left(\mathrm{Mo}_{2} \mathrm{C}\right)$ was found to be active in hydrogenation-related reactions, such as hydrodeoxygenation (HDO) [16-18], hydrodesulfurization (HDS) [18-20], and aromatic compound hydrogenations[18, 21-24]. However, to the best of our knowledge non-precious metal carbides have not been explored for the hydrogenation of dienes.

Moreover, according to previous studies [10,11], the addition of $\mathrm{Ni}$ into the precious metal catalysts would enhance the catalytic performance in the hydrogenation of 1,3-butadiene. Therefore $\mathrm{Ni}$ modified $\mathrm{Mo}_{2} \mathrm{C}$ was also studied in the current paper to further explore the enhancement by Ni addition.

In the current study, we explored the possibility of replacing precious metals by molybdenum carbide $\left(\mathrm{Mo}_{2} \mathrm{C}\right)$ for the hydrogenation of 1,3-butadiene, 1,3-cyclohexadiene (1,3-CHD) and 1,4-cyclohexadiene (1,4-CHD) in a batch reactor, using a supported $\mathrm{Pd} / \mathrm{SiO}_{2}$ catalyst as a reference for comparison. Selective hydrogenation of 1,3-butadiene is an important reaction in industry for the purification of butene stream[25], while 1,3 and 1,4-CHDs are important reaction 
intermediates for hydrogen storage through hydrogenation-dehydrogenation of cyclic hydrocarbons[26]. The $\mathrm{Mo}_{2} \mathrm{C}$ catalyst was further modified by $\mathrm{Ni}$ to determine the effect of metal modification on the hydrogenation activity and selectivity of 1,3-butadiene.

\section{Experimental}

\subsection{Catalyst preparation}

High surface area $\mathrm{SiO}_{2}$ (Alfa Aesar, Stock\#44741,160 m²/g) supported Pd catalyst was synthesized by incipient wetness impregnation, using $\mathrm{Pd}\left(\mathrm{NO}_{3}\right)_{2} \cdot 2 \mathrm{H}_{2} \mathrm{O}$ (Alfa Aesar) as precursor. The metal loading was $0.91 \%$ by weight.

Unsupported $\mathrm{Mo}_{2} \mathrm{C}$ was synthesized by a temperature programmed carburization procedure from $\mathrm{MoO}_{3}$, which was obtained by calcining ammonium molybdate (para) tetrahydrate (Alfa Aesar) in a static muffle furnace at $623 \mathrm{~K}$ for 6 hours. The $\mathrm{MoO}_{3}$ powder was placed in a tube furnace flowing with $20 \% \mathrm{CH}_{4} / \mathrm{H}_{2}$. The total flow rate was $155 \mathrm{~cm}^{3} \mathrm{~min}^{-1}$ for $1 \mathrm{~g} \mathrm{MoO}_{3}$. The temperature was ramped from room temperature to $873 \mathrm{~K}$ at $2 \mathrm{~K} / \mathrm{min}$, and was held for 2 hours. The $\mathrm{CH}_{4}$ stream was cut off after the first hour at $873 \mathrm{~K}$, allowing only $\mathrm{H}_{2}$ flow to remove the extra carbon deposits on the surface of $\mathrm{Mo}_{2} \mathrm{C}$. After cooling to room temperature, the gas flow was switched to $1 \%$ $\mathrm{O}_{2}$ in $\mathrm{N}_{2}$ to passivate the surface defect sites before exposing the catalysts to air.

The Ni modified $\mathrm{Mo}_{2} \mathrm{C}$ catalysts were synthesized by impregnating $\mathrm{Ni}$ onto $\mathrm{MoO}_{3}$ using $\mathrm{Ni}\left(\mathrm{NO}_{3}\right)_{2} \cdot 6 \mathrm{H}_{2} \mathrm{O}$ as precursor. The $\mathrm{Ni} / \mathrm{MoO}_{3}$ powder was then placed into the tube furnace. The temperature program and the gas flow were the same as those in the synthesis of $\mathrm{Mo}_{2} \mathrm{C}$.

\subsection{Characterization}

The $\mathrm{Mo}_{2} \mathrm{C}$ catalyst was characterized using X-ray diffraction (XRD), $\mathrm{N}_{2}$ physisorption by Brunauer-Emmett-Teller (BET) theory, transmission electron microscopy (TEM) and scanning electron microscopy (SEM). The surface area of the support was determined by BET using $\mathrm{N}_{2}$ adsorption-desorption on an Autosorb-1-C instrument. TEM measurements were performed using a JEM-2010 (JEOL Ltd., Tokyo, Japan) operated at $120 \mathrm{kV}$. The catalyst samples were prepared for imaging by 
grinding and suspending $\sim 1 \mathrm{mg}$ of the reduced catalyst in $\sim 5 \mathrm{~mL}$ of ethanol. A pipette was then used to collect the sample from the top of this suspension. Two drops of this solution were deposited onto a lacey support film and dried for 0.5 hour before the TEM measurement. SEM measurements were performed using a JSM 7401F (JEOL Ltd., Tokyo, Japan) instrument operated at $3.0 \mathrm{kV}$.

\subsection{Catalytic evaluation}

The hydrogenation activity was evaluated in a batch reactor which was equipped with Fourier transform infrared (FT-IR) spectroscopy. FT-IR was used to monitor the gas-phase concentrations of reactants and products during the hydrogenation reaction.

The FT-IR spectra were recorded with $4 \mathrm{~cm}^{-1}$ resolution using a Thermo Nicolet Nexus 470 spectrometer equipped with a mercury cadmium telluride (MCT-A) detector. For all FT-IR experiments, $\sim 14 \mathrm{mg}$ of powder catalyst was loaded into the IR cell, which was then evacuated for 12 hours, until the system reached a pressure below $10^{-4} \mathrm{~Pa}$. The catalysts were reduced at $723 \mathrm{~K}$ in $4000 \mathrm{~Pa}$ hydrogen for 30 minutes and the cell was then evacuated, followed by a high temperature flash $(723 \mathrm{~K})$ to remove any surface species generated during the reduction period. The reduction cycle was repeated three times before performing the hydrogenation experiments. After reducing the catalyst, $1040 \mathrm{~Pa}$ diene, $2293 \mathrm{~Pa} \mathrm{H}_{2}$ and $3333 \mathrm{~Pa} \mathrm{He}$ were introduced into the reaction vessel simultaneously, with a diene to hydrogen ratio of 1:2.2. The reaction proceeded in gas phase at a catalyst temperature of $308 \mathrm{~K}$ and a total pressure of $6666 \mathrm{~Pa}$. The catalyst was held static during the reaction. Details of the reactor and the FT-IR detection of the gas-phase components were reported elsewhere[11]. In the regeneration experiments, the $\mathrm{Mo}_{2} \mathrm{C}$ catalsyt was regenerated in $9333 \mathrm{~Pa} \mathrm{H}_{2}$ by performing the same procedure as in the reduction. The reactivity data were collected in the reaction controlled regime because the reactions were measured at a very low starting conversion and the transport should not play a role.

In the current study, the reactions are denoted as follows:

$$
\begin{array}{ll}
\mathrm{C}_{4} \mathrm{H}_{6}+\mathrm{H}_{2} \rightarrow \mathrm{C}_{4} \mathrm{H}_{8} & \text { (Reaction 1) } \\
\mathrm{C}_{4} \mathrm{H}_{8}+\mathrm{H}_{2} \rightarrow \mathrm{C}_{4} \mathrm{H}_{10} & \text { (Reaction 2) }
\end{array}
$$


A first order rate law was used to fit the experimental data and to compare trend between different catalysts. According to previous studies [10,11], the first order reaction showed a good fit of the experimental data of 1,3-butadiene consumption, and the derived reaction rate constants were useful for comparing the trend in different catalysts. For example, the rate laws for the first step and second step hydrogenation of 1,3-butadiene are:

$$
\begin{gathered}
\frac{d C_{A}}{d t}=-r_{1}=-m k_{1} C_{A} \\
\frac{d C_{B}}{d t}=r_{1}-r_{2}=m k_{1} C_{A}-m k_{2} C_{B}
\end{gathered}
$$

where $C_{\mathrm{A}}$ is the concentration of 1,3-butadiene, $C_{\mathrm{B}}$ is the concentration of 1-butene, and $m$ is the weight of catalyst. The concentration of 1,3-butadiene and 1-butene are obtained by integrating Eqs (1) and (2):

$$
\begin{gathered}
\frac{C_{A}}{C_{A 0}}=e^{-m k_{1} t} \\
\frac{C_{B}}{C_{A 0}}=\frac{k_{1}}{k_{2}-k_{1}}\left(e^{-m k_{1} t}-e^{-m k_{2} t}\right)
\end{gathered}
$$

\section{Results and Discussion}

\subsection{Characterization}

The characterization results of $\mathrm{Mo}_{2} \mathrm{C}$ are shown in Fig. 1. The XRD patterns confirm the formation of $\beta-\mathrm{Mo}_{2} \mathrm{C}$ (JCPDS: 35-0787) (1a). The $2 \theta$ values of $34.1,37.6$, $39.5,52.0,61.7,69.5,74.6$, and 75.9 correspond to the (100), (002), (101), (102), (110), (103), (112), and (201) facets of $\beta-\mathrm{Mo}_{2} \mathrm{C}$, respectively. The TEM image shows the lattice of $\mathrm{Mo}_{2} \mathrm{C}(1 \mathrm{~b})$, with the $0.23 \mathrm{~nm}$ and the $0.26 \mathrm{~nm}$ distances corresponding to the (101) and (100) facets, respectively. The $\mathrm{Mo}_{2} \mathrm{C}$ catalyst as synthesized has a low surface area of $5.0 \mathrm{~m}^{2} / \mathrm{g}$ by BET analysis (1c) and the relatively flat surfaces of the $\mathrm{Mo}_{2} \mathrm{C}$ particles are shown in the SEM image (1d). The particle sizes of $\mathrm{Mo}_{2} \mathrm{C}$ and $\mathrm{Ni} / \mathrm{Mo}_{2} \mathrm{C}$ are $0.5-1.5 \mu \mathrm{m}$. 


\subsection{Hydrogenation reactions over $\mathrm{Mo}_{2} \mathrm{C}$}

During the diene hydrogenation reactions in a batch reactor, the gas-phase concentrations of reactants and products are monitored by FT-IR online. Fig. 2 shows the consumption rate of 1,3-butadiene, 1,3-CHD and 1,4-CHD as a function of reaction time. Compared to $\mathrm{Pd} / \mathrm{SiO}_{2}, \mathrm{Mo}_{2} \mathrm{C}$ shows a similar consumption rate of 1,3-butadiene as $\mathrm{Pd} / \mathrm{SiO}_{2}$ (Fig. 2(a)), a similar initial consumption rate of 1,3-CHD (Fig. 2(b)) and a higher consumption rate of 1,4-CHD (Fig. 2(c)).

To make quantitative analysis of hydrogenation activity and rate of deactivation, the hydrogenation reaction rates are estimated by a first order rate law with a second order deactivation for the consumption of reactant dienes, and are normalized by catalyst weight. A second order deactivation model was used to fit the experimental data and to compare the deactivation between different catalysts. It has been found that the second order deactivation fits well for the hydrogenation reactions according to a previous study [27]. The kinetic models for determining the hydrogenation and deactivation rate constants are the same as those described for 1,3-butadiene in a previous study[27]. The normalized rate constants are summarized in Table 1. The reaction rate $\left(k_{\mathrm{r}}\right)$ over $\mathrm{Mo}_{2} \mathrm{C}$ is $13 \%$ - $30 \%$ lower than that over $\mathrm{Pd} / \mathrm{SiO}_{2}$ for 1,3-butadiene and 1,3-CHD hydrogenation reactions, and is 2.9 times higher than that over $\mathrm{Pd} / \mathrm{SiO}_{2}$ for $1,4-\mathrm{CHD}$ hydrogenation. The deactivation rate $\left(k_{\mathrm{d}}\right)$ over $\mathrm{Mo}_{2} \mathrm{C}$ is generally higher than that over $\mathrm{Pd} / \mathrm{SiO}_{2}$ for the three diene molecules. For 1,3-butadiene and 1,4-CHD hydrogenation, the deactivation is almost absent over $\mathrm{Pd} / \mathrm{SiO}_{2}$, and is slightly higher over $\mathrm{Mo}_{2} \mathrm{C}$; however for 1,3-CHD hydrogenation, the deactivation is rather significant over both $\mathrm{Pd} / \mathrm{SiO}_{2}$ and $\mathrm{Mo}_{2} \mathrm{C}$.

The different performance in the hydrogenation reactions is most likely due to the molecular structures. 1,3-butadiene and 1,3-CHD contain conjugated structure and 1,3-CHD and 1,4-CHD contain cyclic structure. The reaction rate of conjugated dienes over $\mathrm{Mo}_{2} \mathrm{C}$ is slightly lower than that over $\mathrm{Pd} / \mathrm{SiO}_{2}$, while the reaction rate of unconjugated diene over $\mathrm{Mo}_{2} \mathrm{C}$ is higher than that over $\mathrm{Pd} / \mathrm{SiO}_{2}$. Compared with 1,3-CHD, the higher activity for 1,4-CHD over $\mathrm{Mo}_{2} \mathrm{C}$ indicates that the conjugation in the diene molecules reduces the $\mathrm{Mo}_{2} \mathrm{C}$ hydrogenation activity. On the other hand, the 
deactivation rate for the three molecules follows the trend of 1,3-butadiene < $1,4-\mathrm{CHD}<1,3-\mathrm{CHD}$, implying that the deactivation rate in the hydrogenation of cyclic dienes is higher than that in the hydrogenation of linear diene, and that the conjugated diene is more easily to deactivate the catalysts than the corresponding unconjugated diene. Assuming that benzene is the precursor for coke formation, 1,3-CHD should have the molecular structure (both cyclic and conjugated) most facile to produce benzene and therefore leading to a faster catalyst deactivation. Other than the molecular structures, the different performance in the hydrogenation reactions might also be related to the different binding structures of the diene molecules on the different catalytic surfaces. The different surface areas of $\mathrm{Pd} / \mathrm{SiO}_{2}$ and the $\mathrm{Mo}_{2} \mathrm{C}$ catalysts might also lead to differences in the hydrogenation activity and selectivity.

Although $\mathrm{Mo}_{2} \mathrm{C}$ is more easily deactivated than $\mathrm{Pd} / \mathrm{SiO}_{2}$, it could be completely regenerated by $\mathrm{H}_{2}$-treatment at $723 \mathrm{~K}$. After performing $\mathrm{H}_{2}$-treatment of the deactivated $\mathrm{Mo}_{2} \mathrm{C}$ catalyst, the consumption curves for the three dienes were very similar to those with the fresh $\mathrm{Mo}_{2} \mathrm{C}$ catalyst (profiles not shown), while the Pd-based catalysts could not be completely regenerated in alkyne/diene hydrogenation reactions due to a complex metal-carbonaceous interaction[9]. Therefore, $\mathrm{Mo}_{2} \mathrm{C}$ is potentially a promising catalyst for diene hydrogenations in terms of both activity and catalytic regeneration.

\subsection{Ni modification for the hydrogenation of 1,3 -butadiene}

The hydrogenation of 1,3-butadiene is used as a probe reaction to evaluate the effect of metal modification on the hydrogenation activity and selectivity of $\mathrm{Mo}_{2} \mathrm{C}$. In 1,3-butadiene hydrogenation, it is nessesary to optimize selectivity to 1-butene, which is the desired hydrogenation product. The 1-butene and butane concentration curves of $\mathrm{Pd} / \mathrm{SiO}_{2}$ and $\mathrm{Mo}_{2} \mathrm{C}$ are plotted in Figs. 3(b)\&(c). Although the hydrogenation rates of 1,3-butadiene are similar over $\mathrm{Pd} / \mathrm{SiO}_{2}$ and $\mathrm{Mo}_{2} \mathrm{C}$, the 1-butene concenration curves in Fig. 3(b) show a much lower 1-butene peak over $\mathrm{Mo}_{2} \mathrm{C}$, indicating a higher 1-butene hydrogenation rate and a lower 1-butene selectivity. It has been reported that

Ni modification on Pd-based catalyst enhances the 1-butene selectivity[10]. Therefore 
$\mathrm{Ni}$ was introduced to the $\mathrm{Mo}_{2} \mathrm{C}$ catalyst for the improvement of the 1-butene selectivity.

Different loadings $(1.5 \%, 6.7 \%, 8.6 \%, 15 \%$ w.t.) of $\mathrm{Ni}$ were impregnated onto $\mathrm{Mo}_{2} \mathrm{C}$. The $\mathrm{Ni} / \mathrm{Mo}_{2} \mathrm{C}$ catalysts were evaluated in the batch reactor and the rate constants of the first hydrogenation step ( $k_{1}$ : 1,3-butadiene $\rightarrow 1$-butene) and the second hydrogenation step ( $k_{2}$ : 1-butene $\rightarrow$ butane) were estimated by a first order law according to Eqs (3) and (4). The values of $k_{1}, k_{2}$ and the selectivity $\left(k_{1} / k_{2}\right)$ are compared in Fig. 4 as a function of Ni loading. The corresponding rate constants and the selectivities of $\mathrm{Mo}_{2} \mathrm{C}$ and $\mathrm{Pd} / \mathrm{SiO}_{2}$ are also included as references (Ni loading is 0 for $\mathrm{Mo}_{2} \mathrm{C}$ ). As shown in Fig. 4, with increasing $\mathrm{Ni}$ loading, the 1,3-butadiene hydrogenation rate remains nearly the same but the 1-butene hydrogenation rate decreases significantly. As a result, the 1-butene selectivity increases with increasing Ni loading. When Ni loading increases to $6.7 \%$, the selectivity reaches the same level of $\mathrm{Pd} / \mathrm{SiO}_{2}$. At a $\mathrm{Ni}$ loading of $8.6 \%$, the selectivity is 0.43 , which is higher than $\mathrm{Pd} / \mathrm{SiO}_{2}$. When Ni loading further increases to $15 \%$, the 1,3-butadiene and 1-butene hydrogenation rates both decrease and the selectivity decreases slightly.

In general, the $\mathrm{Ni} / \mathrm{Mo}_{2} \mathrm{C}$ catalysts retain similar 1,3-butadiene hydrogenation activity as $\mathrm{Mo}_{2} \mathrm{C}$ at $\mathrm{Ni}$ loadings lower than $15 \%$. However on $15 \% \mathrm{Ni} / \mathrm{Mo}_{2} \mathrm{C}$, the 1,3-butadiene hydrogenation rate constant is only $2.7 \mathrm{~min}^{-1} \cdot \mathrm{g} \mathrm{cat}^{-1}$, which is significantly lower than on $\mathrm{Mo}_{2} \mathrm{C}\left(4.2 \mathrm{~min}^{-1} \cdot \mathrm{g} \mathrm{cat}^{-1}\right)$. The large loading of Ni likely covers some active sites on $\mathrm{Mo}_{2} \mathrm{C}$ and inhibits the 1,3-butadiene hydrogenation. On the other hand, increasing $\mathrm{Ni}$ loading leads to a decrease in 1-butene hydrogenation activity, even at low Ni loadings. The different modification effects of $\mathrm{Ni}$ on the hydrogenation rate constants of 1,3-butadiene $\left(k_{1}\right)$ and 1-butene $\left(k_{2}\right)$ are responsible for the enhanced selectivity for 1-butene production.

Comparing the four investigated $\mathrm{Ni} / \mathrm{Mo}_{2} \mathrm{C}$ catalysts, the 1-butene selectivity of $8.6 \% \mathrm{Ni} / \mathrm{Mo}_{2} \mathrm{C}$ is the highest and the 1,3-butadiene hydrogenation activity is still close to $\mathrm{Pd} / \mathrm{SiO}_{2}$. The selectivities of $\mathrm{Mo}_{2} \mathrm{C}$ and $8.6 \% \mathrm{Ni} / \mathrm{Mo}_{2} \mathrm{C}$ are compared with $\mathrm{Pd} / \mathrm{SiO}_{2}$ and $\mathrm{Ni} / \mathrm{SiO}_{2}$ in Table 2. The 1-butene selectivity is 0.22 over $\mathrm{Ni} / \mathrm{SiO}_{2}$ and is 0.11 over $\mathrm{Mo}_{2} \mathrm{C}$, which are both lower than the selectivity of $8.6 \% \mathrm{Ni} / \mathrm{Mo}_{2} \mathrm{C}$, indicating that the 
higher selectivity over $\mathrm{Ni} / \mathrm{Mo}_{2} \mathrm{C}$ does not come from the separate effect of $\mathrm{Mo}_{2} \mathrm{C}$ or Ni.

In a previous study the 1-butene selectivity was enhanced by modification of $\mathrm{Ni}$ in $\mathrm{Ni}-\mathrm{Pd} / \gamma-\mathrm{Al}_{2} \mathrm{O}_{3}$ bimetallic catalysts, and the higher 1-butene selectivity was attributed to the lower binding energy of 1-butene on the Ni-Pd bimetallic structure than on monometallic Pd [10]. Furthermore, Ma et al. [28] reported that Ni showed strong interaction with $\mathrm{Mo}_{2} \mathrm{C}$ on $\mathrm{Ni} / \mathrm{Mo}_{2} \mathrm{C}$, and Porosoff et al [29] reported that $\mathrm{Co}$ formed a $\mathrm{CoMoC}_{\mathrm{y}} \mathrm{O}_{\mathrm{z}}$ phase on $\mathrm{Co} / \mathrm{Mo}_{2} \mathrm{C}$, which might also occur in the case of $\mathrm{Ni} / \mathrm{Mo}_{2} \mathrm{C}$. Both studies suggest that the interaction of $\mathrm{Ni}$ with $\mathrm{Mo}_{2} \mathrm{C}$ should modify the surface electronic properties, possibly leading to a decrease in 1-butene adsorption energy and thus increasing the selectivity.

\subsection{Potential advantage in catalyst cost reduction}

Since the $\mathrm{Ni} / \mathrm{Mo}_{2} \mathrm{C}$ catalyst shows advantage in the selective hydrogenation of 1,3-butadiene, it is important to make a general comparison with $\mathrm{Pd} / \mathrm{SiO}_{2}$ considering both catalyst cost and activity. Cost evaluation is made for $\mathrm{Pd} / \mathrm{SiO}_{2}, \mathrm{Mo}_{2} \mathrm{C}$ and $8.6 \% \mathrm{Ni} / \mathrm{Mo}_{2} \mathrm{C}$ and the results are summarized in Table 3. Here a factor $\alpha$ is defined as follows to compare the catalysts in combining both cost and activity:

$$
\alpha=\frac{\text { Price of catalyt }\left(\mathrm{USD} \cdot \mathrm{kg} \mathrm{cat}{ }^{-1}\right)}{\text { Normalized rate constant }\left(\mathrm{min}^{-1} \cdot \mathrm{g} \mathrm{cat}^{-1}\right)}
$$

As shown in Table 3, by replacing the precious metal with non-precious metal carbide, the value of $\alpha$ decreases by a factor of $\sim 4$, from 0.039 to $0.009 \mathrm{USD} \cdot \mathrm{min}$. However, the $\mathrm{Mo}_{2} \mathrm{C}$ catalyst shows lower selectivity towards 1-butene than $\mathrm{Pd} / \mathrm{SiO}_{2}$, suggesting the limitation of replacing the precious metal catalysts by $\mathrm{Mo}_{2} \mathrm{C}$. By modifying $\mathrm{Mo}_{2} \mathrm{C}$ with $\mathrm{Ni}$, the selectivity increases to the same value of $\mathrm{Pd} / \mathrm{SiO}_{2}$. When the Ni loading is $8.6 \%$, the selectivity is even higher than $\mathrm{Pd} / \mathrm{SiO}_{2}$. Meanwhile, the value $\alpha$ remains similar compared to $\mathrm{Mo}_{2} \mathrm{C}$. The higher 1-butene selectivity and the combined enhancement of activity and cost reduction of $\mathrm{Ni} / \mathrm{Mo}_{2} \mathrm{C}$ over $\mathrm{Pd} / \mathrm{SiO}_{2}$ suggest possible replacement of precious metal catalysts by $\mathrm{Ni}$ modified non-precious metal carbide catalysts. 


\section{Conclusions}

In conclusion, the catalytic hydrogenation of 1,3-butadiene, 1,3-CHD and 1,4-CHD have been compared over $\mathrm{Pd} / \mathrm{SiO}_{2}$ and $\mathrm{Mo}_{2} \mathrm{C}$. The results show that $\mathrm{Mo}_{2} \mathrm{C}$ has similar hydrogenation rate for 1,3-butadiene and 1,3-CHD, and even higher hydrogenation rate for 1,4-CHD. For 1,3-butadine hydrogenation, although $\mathrm{Mo}_{2} \mathrm{C}$ shows similar activity with $\mathrm{Pd} / \mathrm{SiO}_{2}$, it gives lower selectivity to 1-butene. The Ni-modified $\mathrm{Mo}_{2} \mathrm{C}$ catalysts significantly enhance the 1-butene selectivity, with $8.6 \% \mathrm{Ni} / \mathrm{Mo}_{2} \mathrm{C}$ showing the highest selectivity.

Overall, both the $\mathrm{Mo}_{2} \mathrm{C}$ and $\mathrm{Ni} / \mathrm{Mo}_{2} \mathrm{C}$ catalysts show enhancement in combination of activity and catalyst cost reduction. In particular, the combined advantages in activity, selectivity and cost reduction of $\mathrm{Ni} / \mathrm{Mo}_{2} \mathrm{C}$ demonstrate the potential to use less expensive catalysts to replace precious metals for selective hydrogenation reactions.

\section{Acknowledgements}

The work at Columbia University was carried out under Contract No. DE-AC02-98CH10886 with the U.S. Department of Energy, Office of Basic Energy Sciences. R. Hou was sponsored by China Scholarship Council. T.F. Wang was supported by Program for New Century Excellent Talents in University of China (NCET-12-0297). 


\section{References}

[1] Furlong BK, Hightower JW, Chan TYL, Sarkany A, Guczi L (1994) Appl Catal A, 117: 41-51.

[2] Kripylo P, Turek F, Hempe KD, Kirmse H (1975) Chem Tech (Leipzig) 27: 675-679.

[3] Hightower JW, Furlong B, Sarkany A, Guczi L (1993) Stud Surf Sci Catal 75: 2305-2308.

[4] Sarkany A, Stefler G, Hightower JW (1995) Appl Catal A, 127: 77-92.

[5] Qi S, Yu W, Lonergan WW, Yang B, Chen JG (2010) Chin J Catal 31: 955-960.

[6] Qi S, Yu W, Lonergan WW, Yang B, Chen JG (2010) ChemCatChem, 2: 625-628.

[7] Schrock RR, Osborn JA (1976) J Am Chem Soc 98: 4450-4455.

[8] Miura H, Terasaka M, Oki K, Matsuda T (1993) Stud Surf Sci Catal 75: 2379-2382.

[9] Hugon A, Delannoy L, Krafft J-M, Louis C (2010) The Journal of Physical Chemistry C, 114: 10823-10835.

[10] Hou R, Yu W, Porosoff MD, Chen JG, Wang T (2014) J Catal 316: 1-10.

[11] Lonergan WW, Vlachos DG, Chen JG (2010) J Catal 271: 239-250.

[12] Lonergan WW, Xing XJ, Zheng RY, Qi ST, Huang B, Chen JG (2011) Catal Today 160: 61-69.

[13] Piccolo L (2013) Chem Commun 49: 9149-9151.

[14] Hwu HH, Chen JG (2005) Chem Rev 105: 185-212.

[15] Oyama S (1992) Catal Today 15: 179-200.

[16] Ren H, Yu W, Salciccioli M, Chen Y, Huang Y, Xiong K, Vlachos DG, Chen JG (2013) ChemSusChem, 6: 798-801.

[17] Boullosa-Eiras S, Lødeng R, Bergem H, Stöcker M, Hannevold L, Blekkan EA (2014) Catal Today 223: 44-53.

[18] Dhandapani B, St Clair T, Oyama S (1998) Appl Catal A, 168: 219-228.

[19] McCrea KR, Logan JW, Tarbuck TL, Heiser JL, Bussell ME (1997) J Catal 171: 255-267. 
[20] Szymańska-Kolasa A, Lewandowski M, Sayag C, Djéga-Mariadassou G (2007) Catal Today 119: 7-12.

[21] Lee JS, Yeom MH, Park KY, Nam I-S, Chung JS, Kim YG, Moon SH (1991) J Catal 128: 126-136.

[22] Da Costa P, Potvin C, Manoli JM, Breysse M, Djéga-Mariadassou G (2001) Catal Lett 72: 91-97.

[23] St. Clair T, Dhandapani B, Oyama ST (1999) Catal Lett 58: 169-171.

[24] Mamède AS, Giraudon JM, Löfberg A, Leclercq L, Leclercq G (2002) Appl Catal A, 227: 73-82.

[25] Alves JA, Bressa SP, Martinez OM, Barreto GF (2004) Chem Eng J 99: 45-51. [26] Schlapbach L, Züttel A (2001) Nature, 414: 353-358.

[27] Wang T, Mpourmpakis G, Lonergan WW, Vlachos DG, Chen JG (2013) Phys Chem Chem Phys 15: 12156-12164.

[28] Ma YF, Guan GQ, Phanthong P, Hao XG, Huang W, Tsutsumi A, Kusakabe K, Abudula A (2014) J Phys Chem C 118: 9485-9496.

[29] Porosoff MD, Yang X, Boscoboinik JA, Chen JG (2014) Angew Chem Int Ed 126: $6823-6827$. 


\section{Figure Captions}

Fig. 1 Characterizations of $\mathrm{Mo}_{2} \mathrm{C}$ : (a) XRD; (b) TEM; (c) BET; (d) SEM

Fig. 2 Consumption rate of (a) 1,3-butadiene (b) 1,3-CHD (c) 1,4-CHD over $\mathrm{Mo}_{2} \mathrm{C} .(T=308 \mathrm{~K}$, $P_{\mathrm{H} 2}=2293 \mathrm{~Pa}, P_{\text {Diene }}=1040 \mathrm{~Pa}$, and $\left.\mathrm{P}_{\mathrm{He}}=3333 \mathrm{~Pa}\right)$

Fig. 3 Consumption rate of (a) 1,3-butadiene and production rates of (b) 1-butene and (c) butane. $\left(T=308 \mathrm{~K}, P_{\mathrm{H} 2}=2293 \mathrm{~Pa}, P_{\text {Diene }}=1040 \mathrm{~Pa}\right.$, and $\left.\mathrm{P}_{\mathrm{He}}=3333 \mathrm{~Pa}\right)$

Fig. 4 Normalized reaction rate constants and the estimated selectivity on different loadings of $\mathrm{Ni} / \mathrm{Mo}_{2} \mathrm{C}\left(k_{1}: 1,3\right.$-butadiene $\rightarrow$ 1-butene; $k_{2}$ : 1-butene $\rightarrow$ butane)

\section{Table Captions}

Table 1 Summary of normalized reaction rate constants and deactivation rates on $\mathrm{Mo}_{2} \mathrm{C}$ and $\mathrm{Pd} / \mathrm{SiO}_{2}$ for the hydrogenation of dienes

Table 2 Selectivity comparison of supported $\mathrm{Pd}$ and $\mathrm{Ni}$ catalysts with $\mathrm{Mo}_{2} \mathrm{C}$ and $\mathrm{Ni} / \mathrm{Mo}_{2} \mathrm{C}$ catalysts

Table 3 Cost evaluation of $\mathrm{Pd} / \mathrm{SiO}_{2}, \mathrm{Mo}_{2} \mathrm{C}$ and $8.6 \% \mathrm{Ni} / \mathrm{Mo}_{2} \mathrm{C}$ for 1,3 -butadiene hydrogenation 

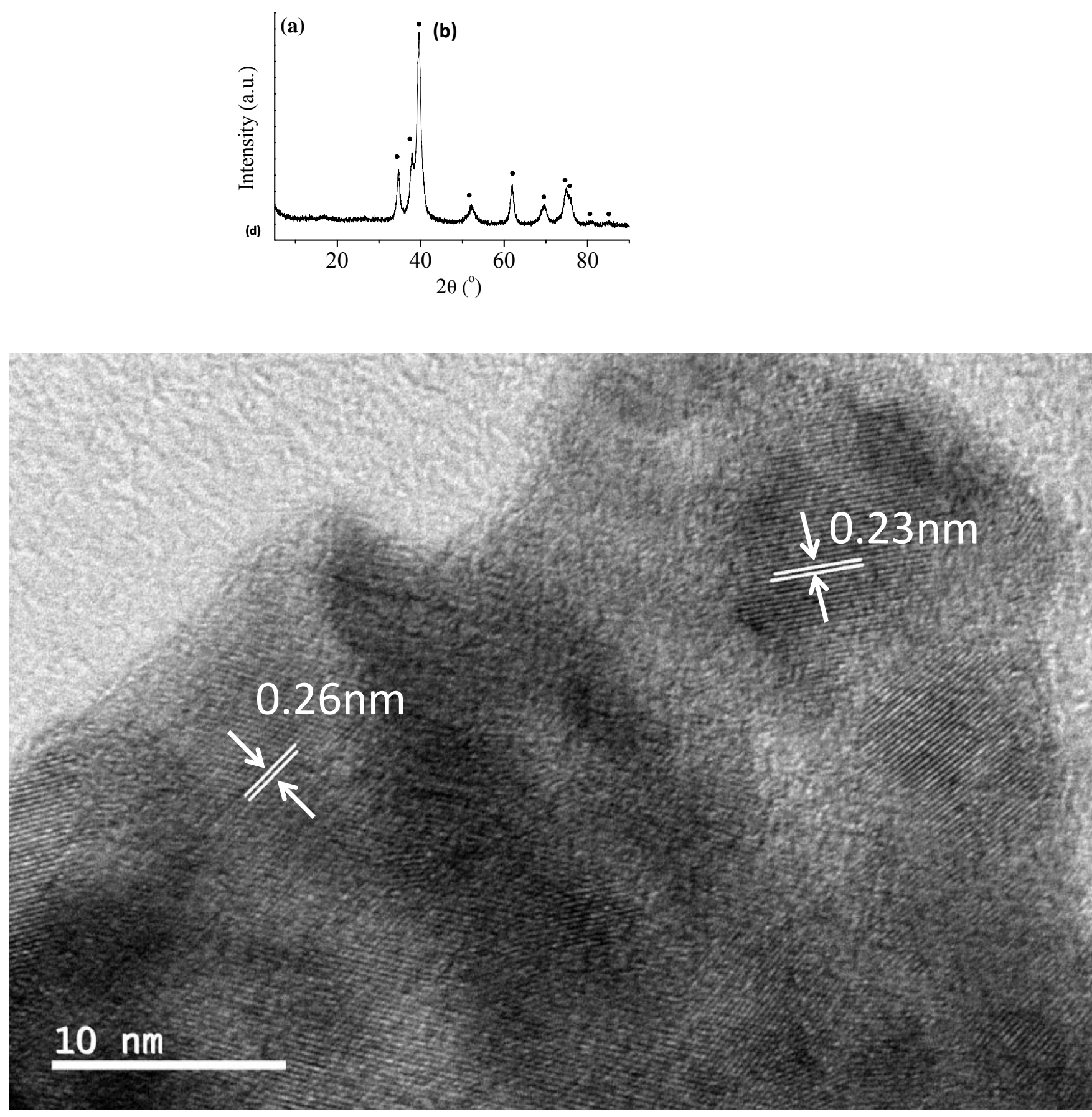

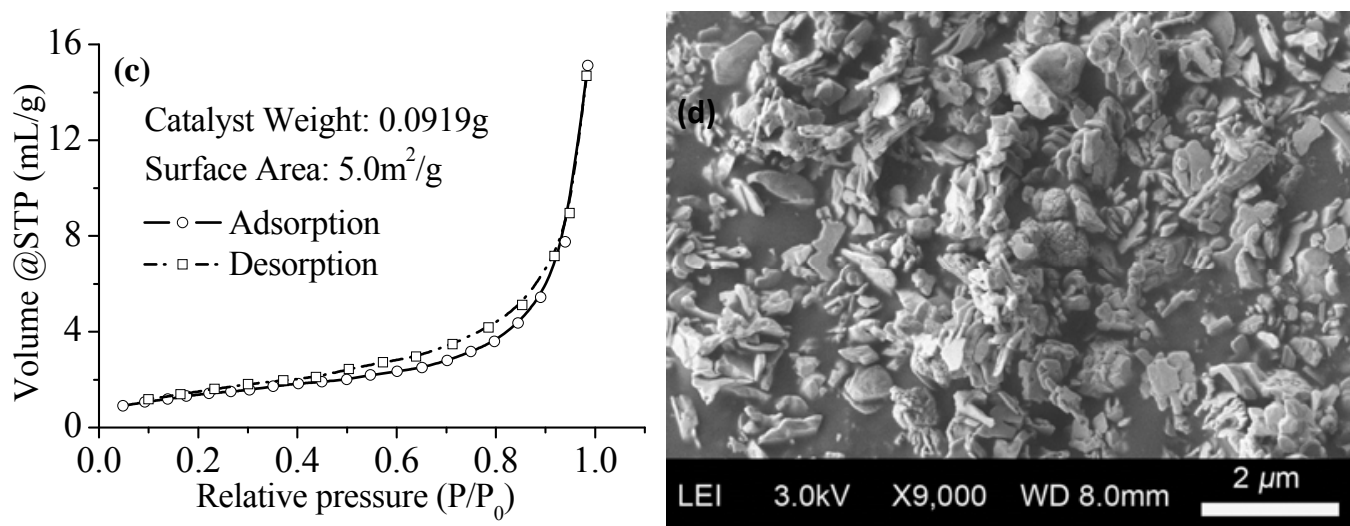

Fig. 1 Characterizations of $\mathrm{Mo}_{2} \mathrm{C}$ : (a) XRD; (b) TEM; (c) BET; (d) SEM
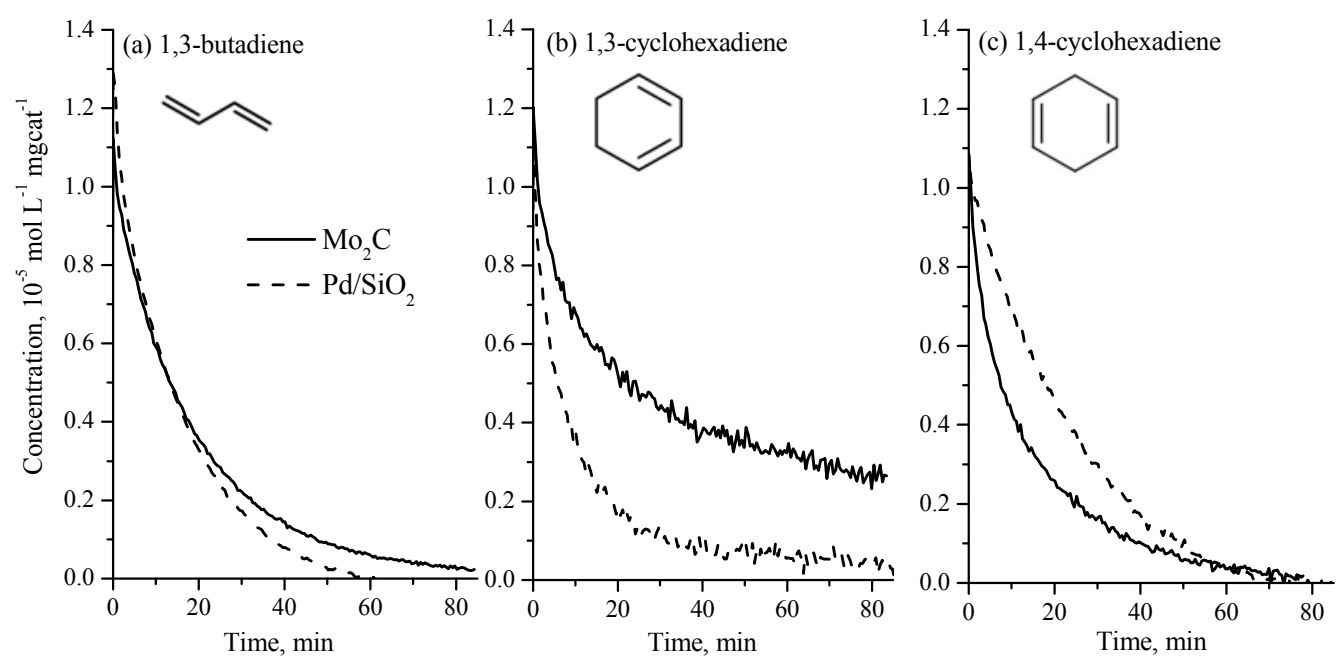

Fig. 2 Consumption rate of (a) 1,3-butadiene (b) 1,3-CHD (c) 1,4-CHD over $\mathrm{Mo}_{2} \mathrm{C} .(T=308 \mathrm{~K}$,

$$
\left.P_{\mathrm{H} 2}=2293 \mathrm{~Pa}, P_{\text {Diene }}=1040 \mathrm{~Pa} \text {, and } \mathrm{P}_{\mathrm{He}}=3333 \mathrm{~Pa}\right)
$$



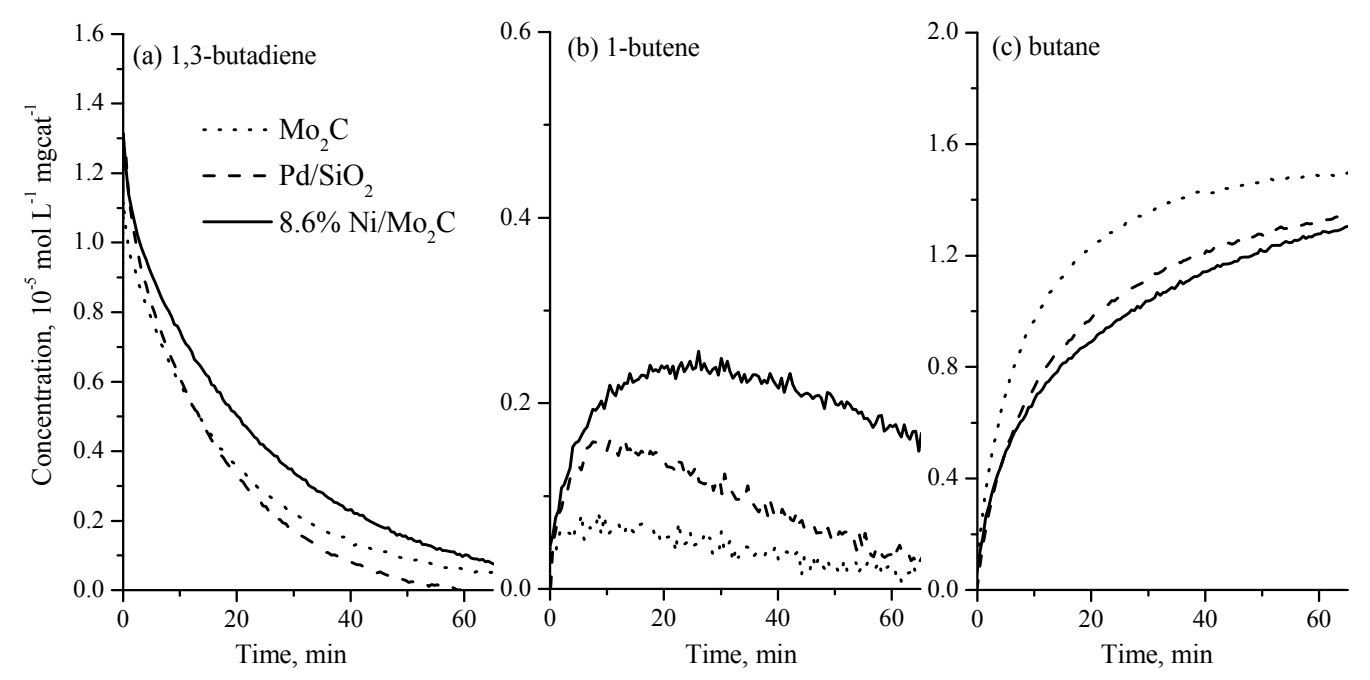

Fig. 3 Consumption rate of (a) 1,3-butadiene and production rates of (b) 1-butene and (c) butane. $\left(T=308 \mathrm{~K}, P_{\mathrm{H} 2}=2293 \mathrm{~Pa}, P_{\text {Diene }}=1040 \mathrm{~Pa}\right.$, and $\left.\mathrm{P}_{\mathrm{He}}=3333 \mathrm{~Pa}\right)$

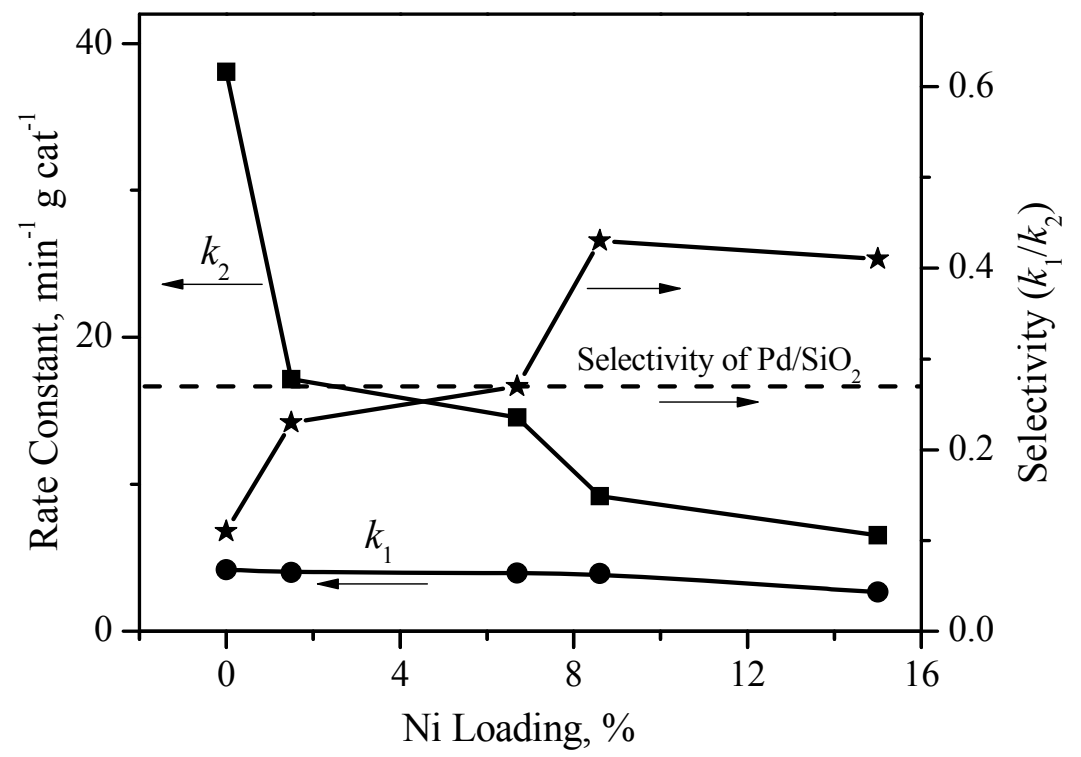

Fig. 4 Normalized reaction rate constants and the estimated selectivity on different loadings of $\mathrm{Ni} / \mathrm{Mo}_{2} \mathrm{C}\left(k_{1}: 1,3\right.$-butadiene $\rightarrow$ 1-butene; $k_{2}:$ 1-butene $\rightarrow$ butane $)$ 
Table 1 Summary of normalized reaction rate constants and deactivation rates on $\mathrm{Mo}_{2} \mathrm{C}$ and $\mathrm{Pd} / \mathrm{SiO}_{2}$ for the hydrogenation of dienes

\begin{tabular}{ccccc}
\hline $\begin{array}{c}\text { Normalized Rate Constant } \\
\left(\mathrm{min}^{-1} \cdot \mathrm{g} \mathrm{cat}^{-1}\right)\end{array}$ & 1,3-butadiene & 1,3-cyclohexadiene & 1,4-cyclohexadiene \\
\hline \multirow{2}{*}{$\mathrm{Pd} / \mathrm{SiO}_{2}$} & $k_{r}$ & 6.1 & 12.2 & 3.1 \\
& $k_{d}$ & 0.7 & 15.5 & 0 \\
\hline \multirow{2}{*}{$\mathrm{Mo}_{2} \mathrm{C}$} & $k_{r}$ & 5.3 & 8.6 & 8.9 \\
& $k_{d}$ & 1.3 & 18.0 & 4.9 \\
\hline
\end{tabular}

Table 2 Selectivity comparison of supported $\mathrm{Pd}$ and $\mathrm{Ni}$ catalysts with $\mathrm{Mo}_{2} \mathrm{C}$ and $\mathrm{Ni} / \mathrm{Mo}_{2} \mathrm{C}$ catalysts

\begin{tabular}{cc}
\hline Catalyst & Selectivity $\left(k_{1} / k_{2}\right)$ \\
\hline $0.9 \% \mathrm{Pd} / \mathrm{SiO}_{2}$ & 0.27 \\
$1.5 \% \mathrm{Ni} / \mathrm{SiO}_{2}$ & 0.22 \\
$\mathrm{Mo}_{2} \mathrm{C}$ & 0.11 \\
$8.6 \% \mathrm{Ni} / \mathrm{Mo}_{2} \mathrm{C}$ & 0.43 \\
\hline
\end{tabular}

Table 3 Cost evaluation of $\mathrm{Pd} / \mathrm{SiO}_{2}, \mathrm{Mo}_{2} \mathrm{C}$ and $8.6 \% \mathrm{Ni} / \mathrm{Mo}_{2} \mathrm{C}$ for 1,3 -butadiene hydrogenation

\begin{tabular}{ccccc}
\hline Catalyst & $\begin{array}{c}\text { Price }^{*} \\
\left(\mathrm{USD} \cdot \mathrm{kg} \mathrm{cat}^{-1}\right)\end{array}$ & $\begin{array}{c}k_{1} \\
\left(\mathrm{~min}^{-1} \cdot \mathrm{g} \mathrm{cat}^{-1}\right)\end{array}$ & $\begin{array}{c}\alpha \\
\left(10^{-3} \cdot \mathrm{USD} \cdot \mathrm{min}\right)\end{array}$ & $\begin{array}{c}\text { Selectivity } \\
\left(k_{1} / k_{2}\right)\end{array}$ \\
\hline $\mathrm{Pd} / \mathrm{SiO}_{2}$ & 216.27 & 5.6 & 38.6 & 0.27 \\
$\mathrm{Mo}_{2} \mathrm{C}$ & 39.48 & 4.2 & 9.4 & 0.11 \\
$8.6 \% \mathrm{Ni} / \mathrm{Mo}_{2} \mathrm{C}$ & 38.41 & 3.9 & 9.8 & 0.43 \\
\hline
\end{tabular}

\footnotetext{
${ }^{*}$ The prices are from www.metalprice.com
} 